\title{
Cutaneous lesions and finger clubbing uncovering hypocomplementemic urticarial vasculitis and hepatitis $C$ with mixed cryoglobulinemia*
}

\author{
Lesões cutâneas e baqueteamento digital reveladores de vasculite urticariforme \\ hipocomplementêmica e hepatite C com crioglobulinêmia mista
}

\author{
Teresa Pinto-Almeida ${ }^{1}$
}

Mónica Caetano ${ }^{1}$

Rosário Alves ${ }^{1}$

Manuela Selores ${ }^{1}$

DOI: http://dx.doi.org/10.1590/abd1806-4841.20132776

\begin{abstract}
Urticarial vasculitis is a rare clinicopathologic entity characterized by urticarial lesions that persist for more than 24 hours and histologic features of leukocytoclastic vasculitis. Patients can be divided into normocomplementemic or hypocomplementemic. The authors report the case of a healthy 49-year-old woman with a 1-year history of highly pruritic generalized cutaneous lesions and finger clubbing. Laboratory tests together with histopathologic examination allowed the diagnosis of hypocomplementemic urticarial vasculitis, chronic hepatitis $\mathrm{C}$ and type II mixed cryoglobulinemia. The patient started symptomatic treatment and was referred to a gastroenterologist for management of the hepatitis $C$, with progressive improvement of the skin condition. The development of hypocomplementemic urticarial vasculitis in the context of chronic hepatitis $\mathrm{C}$ is exceedingly rare and possible pathogenic mechanisms are discussed.
\end{abstract}

Keywords: Complement C1q; Complement C3; Complement C4; Cryoglobulinemia; Hepatitis C, chronic; Systemic vasculitis; Urticaria; Vasculitis

Resumo: A vasculite urticariforme é uma entidade clinico-patológica rara caracterizada por lesões urticariformes com duração superior a 24 horas e uma vasculite leucocitoclásica na histologia. É dividida em normo e hipocomplementêmica. Os autores relatam o caso de uma mulher saudável de 49 anos, com lesões cutâneas intensamente pruriginosas e baqueteamento digital com 1 ano de evolução. O estudo efectuado permitiu efectuar os diagnósticos de vasculite urticariforme hipocomplementêmica, hepatite C crônica e crioglobulinêmia mista tipo II. A doente iniciou tratamento sintomático e foi referenciada para a Gastroenterologia para orientação da hepatite, com melhoria progressiva das lesões cutâneas. O desenvolvimento de vasculite urticariforme hipocomplementêmica no contexto de hepatite $\mathrm{C}$ crónica é raro e os possíveis mecanismos patogênicos são discutidos.

Palavras-chave: Complemento C1q; Complemento C3; Complemento C4; Crioglobulinemia; Hepatite C crônica; Urticária; Vasculite; Vasculite sistêmica

\section{INTRODUCTION}

The authors report a case of hypocomplementemic urticarial vasculitis and finger clubbing that developed in the setting of chronic hepatitis C and type II mixed cryoglobulinemia. Possible etiologic association is discussed and treatment is further addressed.

\section{CASE REPORT}

A 49-year-old woman presented with a 1-year history of highly pruritic generalized cutaneous lesions. She denied systemic symptoms. She was otherwise healthy and was on no regular medication. Physical examination revealed localized urticarial wheals and purpuric macules on the forearms, wrists,

\footnotetext{
Received on 14.05.2013.

Approved by the Advisory Board and accepted for publication on 19.06.2013.

* Work performed at the Dermatology Service, Centro Hospitalar do Porto - Hospital de Santo António - Porto, Portugal.

Financial Support: none

Conflict of Interests: none

M.D. - Dermatologist, Department of Dermatology, Centro Hospitalar do Porto - Hospital de Santo António, Porto, Portugal.

C2013 by Anais Brasileiros de Dermatologia
}

An Bras Dermatol. 2013;88(6):973-6. 
thighs, legs and dorsum of the feet; according to the patient, the lesions lasted longer than 24 hours and resolved with hyperpigmentation (Figures 1-4). Finger clubbing was also evident (Figure 5). There were no other findings on physical examination. Histopathologic examination of a cutaneous lesion showed a perivascular inflammatory infiltrate in the superficial and mid dermis, composed mainly of polymorphonuclear neutrophils and rare eosinophils, associated with fibrinoid necrosis of the vascular wall and leukocytoclasia (Figure 6). These features were consistent with a leukocytoclastic vasculitis. Laboratory tests disclosed increased liver enzymes (ALT 90 U/L, normal 10-30, AST 96 U/L, normal 1036), positive anti-hepatitis $\mathrm{C}$ virus (HCV) antibodies with high titres of serum HCV RNA (720000 UI/L), low complement levels (C1q $3.0 \mathrm{mg} / \mathrm{dL}$, normal 12.220.8; C4 $<2 \mathrm{mg} / \mathrm{dL}$, normal 12-42) and type II mixed cryoglobulinemia (cryoglobulins $187 \mathrm{mcg} / \mathrm{mL}$, mixed type II IgG-IgM/Kappa). The remainder of the laboratory tests were negative or within the normal range. Abdominal ultrasound showed diffuse hepatic steato-

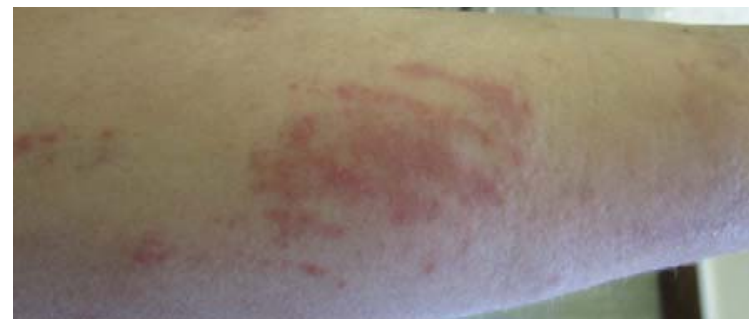

Figure 1: Clinical features of the cutaneous lesionson the left forearm

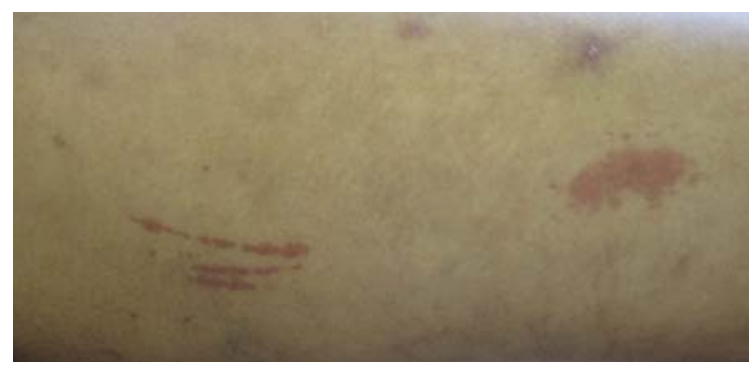

FigURE 2: Urticarial wheals on the left thigh

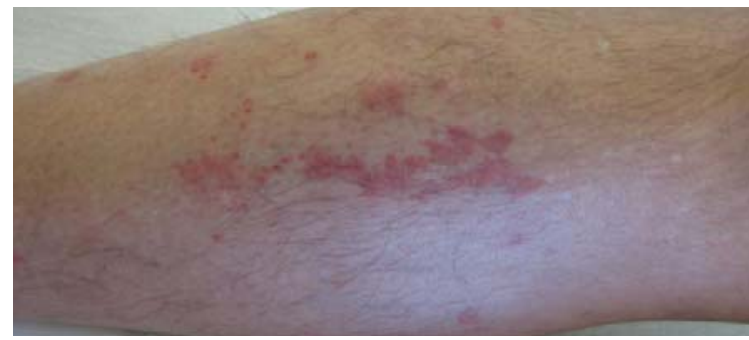

FIGURE 3: Highlight of the lesions on the right leg

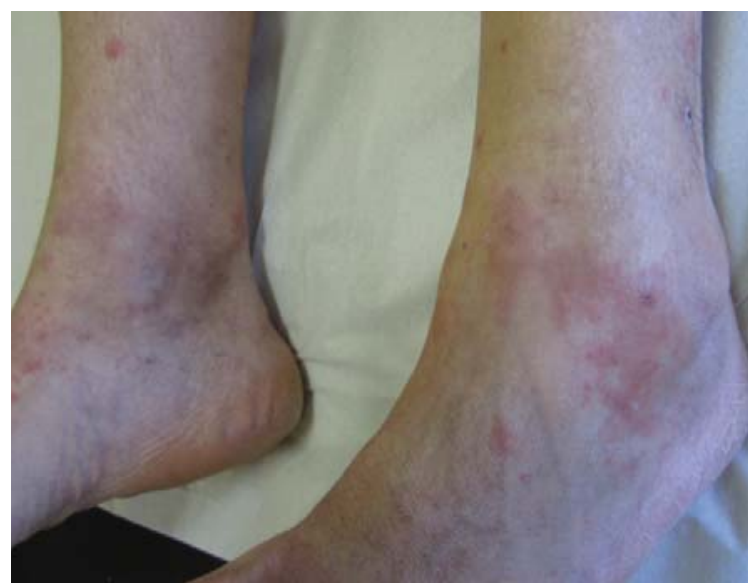

FIGURE 4: Involvement of the dorsum of the feet

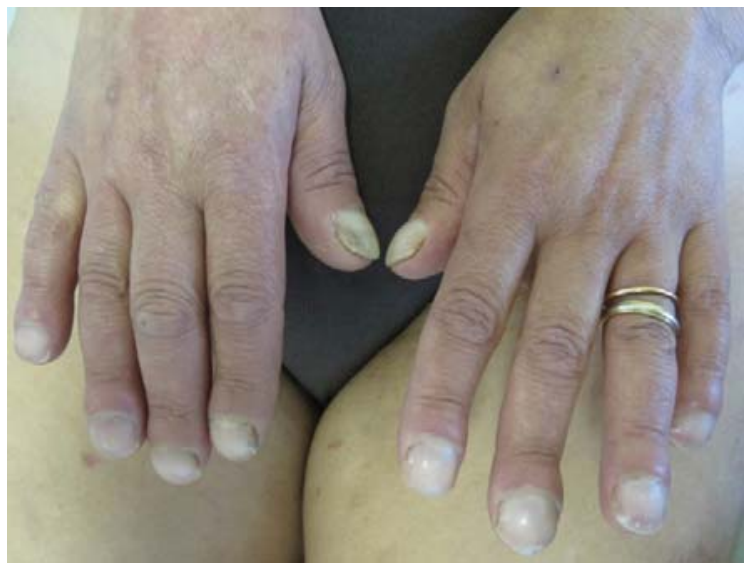

Figure 5: Finger clubbing

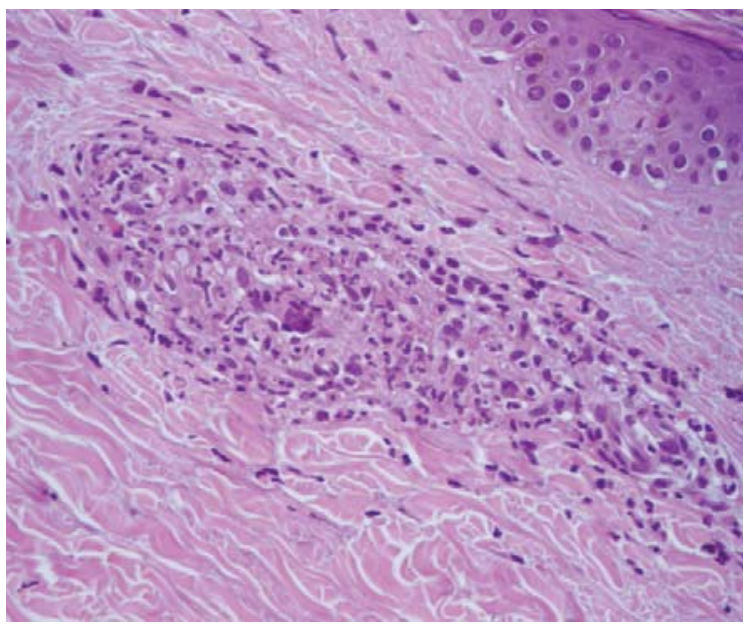

FIGURE 6: Histopathologic examination of a cutaneous lesion showing a perivascular inflammatory infiltrate, composed mainly of polymorphonuclear neutrophils, associated with fibrinoid necrosis of the vascular wall and leukocytoclasia (hematoxylin and eosin, original magnification 40x). 
sis and thorax x-ray was unremarkable. Altogether clinical, laboratory and histopathological findings allowed the diagnosis of hypocomplementemic urticarial vasculitis and hepatitis $C$ with myxed cryoglobulinemia. The patient started symptomatic treatment with hydroxyzine $25 \mathrm{mg}$ PO bid, with partial control of the pruritus, and was referred to a gastroenterology consultation for management of the hepatic condition. A liver biopsy was performed and showed features of chronic hepatitis with scarce fibrosis. In the meantime, liver enzyme levels returned to the normal range (ALT $22 \mathrm{U} / \mathrm{L}$, normal 10-30, AST $28 \mathrm{U} / \mathrm{L}$, normal 10-36). This was accompanied by progressive clearance of cutaneous lesions and resolution of the pruritus; residual hypopigmentation persisted in the sites of previous scratching. Given the benign liver pathology and the lack of hepatitis $C$ activity, it was decided by the gastroenterology specialist not to start any kind of treatment but to keep the patient under close surveillance instead. The cutaneous condition remains stable after one year of follow-up, similar to the hepatic disease course.

\section{DISCUSSION}

Urticarial vasculitis is a rare clinicopathologic entity characterized by urticarial lesions that typically persist for more than 24 hours and by histologic features of leukocytoclastic vasculitis. ${ }^{1-5}$ Cutaneous lesions are accompanied by burning or painful sensations and pruritus and frequently resolve with residual hyperpigmentation or purpura. ${ }^{1-5}$ It can be a local idiopathic process or be associated with systemic diseases, mainly autoimmune connective tissue diseases, infections (including viral hepatitis), drugs or malig- nancies. ${ }^{1-5}$ Two types are distinguished: those with normal complement levels and hypocomplementemic urticarial vasculitis (HUV). Patients with HUV are more likely to have chronic disease with multisystemic involvement; extracutaneous manifestations include arthralgia, abdominal pain, obstructive lung disease, nephritis, uveitis, among others.$^{1-5}$ When facing the diagnosis of urticarial vasculitis it is mandatory to exclude underlying systemic diseases. Finger clubbing in our patient was an additional suggestive factor, since its presence is commonly related to internal involvement and has been described in the literature in association with cutaneous vasculitis in the setting of underlying systemic diseases.$^{6,7} \mathrm{HCV}$ infection is related to several cutaneous manifestations, which can be the presenting sign of the disease. The development of HUV in this context is exceedingly rare and can be explained by the presence of mixed cryoglobulinemia, with the consequent activation of the complement pathway and consumption of complement factors, or by the intrinsic immunopathogenic mechanisms of $\mathrm{HCV}$, though not yet completely elucidated. ${ }^{8}$ Even in the absence of systemic symptoms, patients with HUV need a careful follow-up given the fact that progression to a multisystemic syndrome is not uncommon. Treatment is directed to the underlying condition and prognosis depends on the systemic involvement. ${ }^{1-5}$ In our patient, the causative role of hepatitis $C$ in the development of urticarial vasculitis is suggested by the temporal association and assumption of the most probable cause. This hypothesis was confirmed by the response of cutaneous lesions and pruritus to the loss of activity of the hepatic disease. $\square$ 


\section{REFERENCES}

1. Peroni A, Colato C, Zanoni G, Girolomoni G. Urticarial lesions: if not urticarial, what else? The differential diagnosis of urticarial. Part II. Systemic diseases. J Am Acad Dermatol. 2010;62:557-70.

2. Fiorentino DF. Cutaneous vasculitis. J Am Acad Dermatol. 2003;48:311-40.

3. Chen KR, Carlson JA. Clinical approach to cutaneous vasculitis. Am J Clin Dermatol. 2008;9:71-92.

4. Russell JP, Gibson LE. Primary cutaneous small vessel vasculitis: approach to diagnosis and treatment. Int J Dermatol. 2006;45:3-13.

5. Brandt HRC, Arnone M, Vanelte NYS, Criado PR, Sotto MN. Small vessel cutaneous vasculitis: etiology, pathogenesis, classification and diagnostic criteria Part I. An Bras Dermatol. 2007;82:387-406.

6. Spicknall KE, Zirwas MJ, English JC 3rd. Clubbing: an update on diagnosis, differential diagnosis, pathophysiology and clinical relevance. J Am Acad Dermatol. 2005;52:1020-8

7. Miyachi H, Akizuki M, Yamagata H, Mimori T, Yoshida S, Homma M. Hypertrophic osteoarthropathy, cutaneous vasculitis, and mixed-type cryoglobulinemia in a patient with nasopharyngeal carcinoma. Arthritis Rheum. 1987;30:825-9.

8. Saadoun D, Sadallah S, Trendelenburg M, Limal N, Sene D, Piette JC, et al. AntiC1q antibodies in hepatitis C virus infection. Clin Exp Immunol. 2006;145:308-12.
MAILING ADDRESS:

Teresa Pinto-Almeida

Serviço de Dermatologia

Hospital de Santo António

Edifício das Consultas Externas, Ex-CICAP,

Rua D. Manuel II, s/n

4100 - Porto - Portugal

E-mail: teresap.almeida@hotmail.com

How to cite this article: Pinto-Almeida T, Caetano M, Alves R, Selores M. Cutaneous lesions and finger clubbing uncovering hypocomplementemic urticarial vasculitis and hepatitis $\mathrm{C}$ with mixed cryoglobulinemia. An Bras Dermatol. 2013;88(6)973-6. 